\title{
Design and operation of closed-loop triple-deck buck-boost converter with high gain soft switching
}

\author{
S. Narasimha ${ }^{1}$, Surender Reddy Salkuti ${ }^{2}$ \\ ${ }^{1}$ Department of Electrical and Electronics Engineering, TKR College of Engineering and Technology, India \\ ${ }^{2}$ Department of Railroad and Electrical Engineering, Woosong University, Daejeon, Republic of Korea
}

\begin{tabular}{l} 
Article Info \\
\hline Article history: \\
Received Sep 23, 2019 \\
Revised Nov 9, 2019 \\
Accepted Dec 2, 2019 \\
\hline
\end{tabular}

Keywords:

Buck-boost converter

Closed loop system

Duty ratio

PI controller

Soft switching

Zero voltage switching

\begin{abstract}
This paper presents the design and operation of three-stage buck-boost converter with high gain soft switching using closed loop proportional integral (PI) controller. The proposed converter is designed by arranging three identical buck-boost converters working in parallel. The converter units are connected to each other by an inductor as a bridge. This inductor plays a vital role in soft switching operation of converter by maintaining the voltage applied to switches at zero voltage at switching intervals, i.e., the zerovoltage switching (ZVS). The closed-loop system is designed by PI controller, and it maintains the output constant irrespective of changes in input, and the system becomes stable. The proposed converter is efficient in reducing switching losses, leading to improved converter efficiency. Due to parallel operation of three identical converters, the output voltage and input current contain fewer ripples than those of a single converter with same specifications. Proposed converter is more economical and reliable with simpler structure as it utilizes only two inductors as extra elements. The design and analysis of proposed circuit has been carried out in MATLAB Simulink by operating the circuit in various modes.
\end{abstract}

This is an open access article under the CC BY-SA license.

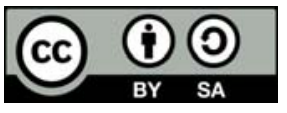

\section{Corresponding Author:}

Surender Reddy Salkuti, Department of Railroad and Electrical Engineering, Woosong University, 17-2, Jayang-Dong, Dong-Gu, Daejeon - 34606, Republic of Korea.

Email: surender@wsu.ac.kr

\section{INTRODUCTION}

Nowadays, DC/DC converters are utilized for various reasons when the conversion between two dc voltage levels, such as electrical vehicles, dynamic filters, power factor correction circuits, appropriated ages, $\mathrm{dc} / \mathrm{dc}$ regulated power supplies, etc. is required. A buck-boost converter is an exchanged mode power supply that consolidates the standards of buck converter, and the boost converter in a solitary circuit. Recently, interleaved converters are used in various applications and give many focal points, such as expanding efficiency, decreasing the voltage and current ripples, and providing high load power. The efficiency of dc/dc converters is an important issue. Therefore, different control methodologies and converter topologies are proposed for the delicate switching operation of converters to accomplish least switching losses, improved efficiency and effective operations [1].

A new two-stage buck-boost converter with a soft switching operation with two identical buck-boost converters working in parallel is proposed in reference [2]. In reference [3], a double-deck buck-boost converter with soft switching capability by parasitic capacitors is constructed with two identical buck-boost converters working in parallel. Reference [4] proposes a new structure-stage buck-boost converter with a soft 
level switching operation with feedback proportional integral (PI) loop control. A double-deck converter with a PI controller is proposed in [5], which provides a decent efficiency under both buck and boost modes. A two-stage buck-boost converter with two identical buck-boost converters working in parallel and soft switching operation for renewable energy applications is proposed in reference [6]. A new M-SEPIC dc-dc converter fed brushless-DC motor drive is controlled by voltage source inverter and powered by single-phase grid system with improved power-quality features is proposed in reference [7].

A double-stage buck-boost converter with zero-voltage switching (ZVS) capability is proposed in reference [8]. A transformerless buck-boost dc-dc converter has been proposed in reference [9]. A voltage regulated two stage buck-boost converter with a soft switching operation is proposed in [10]. Reference [11] proposes an active-clamp ZVS buck-boost converter to improve the performance of converter during light loading condition. Comparison of various dc-dc converters for solar photovoltaic (PV) systems has been presented in reference [12]. Design and implementation of buck-boost converter for its application to stabilize voltage has been proposed in reference [13]. Reference [14] proposes two quasi-Z-source dc-dc converters (q-ZSCs) with buck-boost converter gain.

The design and operation of three-stage buck-boost converter with soft switching using closed loop PI controllers has been proposed in the present paper. The proposed converter is constructed by arranging three identical buck-boost converters working in parallel. The converter units are connected to each other by an inductor as a bridge. This inductor plays a vital role in soft switching operation of converter by maintaining the voltage applied to switches is zero at switching intervals, i.e., zero-voltage switching (ZVS). The system is made closed loop by PI controller which maintains the output constant irrespective of changes in the input, i.e., system is stable. The proposed converter is efficient in reducing the switching losses and leading to improved converter efficiency.

The rest of this paper is organized as follows. Section 2 presents the description of proposed tripledeck buck-boost converter. Section 3 describes the implementation of closed-loop triple-deck buck-boost converter. Section 4 presents the discussion of numerical results. Finally, Section 5 of the article depicts the contributions with concluding remarks.

\section{TRIPLE-DECK BUCK-BOOST CONVERTER}

Figure 1 depicts the schematic diagram of buck-boost converter. A control unit is incorporated in it and it is used to detect the level of information voltage, and that point is chosen for fitting circuit activity [15]. MOSFETs are utilized as a part of high recurrence power converters, and the diodes appeared as Schottky sorts. These diodes have a low forward intersection voltage when leading, and can switch at high speeds. This converter is useful in self regulating power supplies and in battery control frameworks. They have less voltage ripples, low voltage on MOSFETs, and high efficiency [16].

Figure 2 depicts the schematic diagram of triple-deck buck-boost converter which consists of three identical buck boost converters which are connected in parallel through interleaved inductors [17]. Here, the load is connected across capacitor [18].

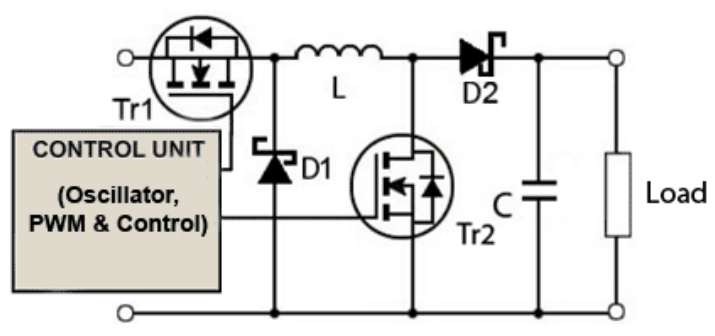

Figure 1. Schematic diagram of buck-boost converter

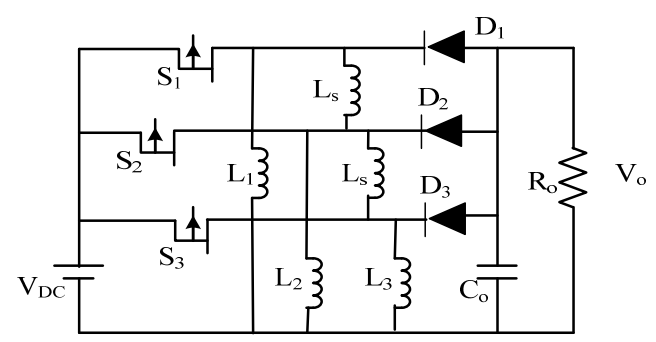

Figure 2. Schematic diagram of triple-deck buckboost converter

\subsection{Closed loop triple-deck buck-boost converter}

Figure 3 depicts the schematic diagram of closed loop triple-deck buck-boost converter, in which the output voltage $\left(\mathrm{V}_{\mathrm{o}}\right)$ is fed back to PI controller to detect the error and make the necessary correction as per the required or desired output by adding or subtracting the gain as per the error detected [19].

Int J Pow Elec \& Dri Syst Vol. 11, No. 1, Mar 2020 : 523 - 529 
Various types of controllers include proportional controller, integral controller, differential controller, proportional integral controller [20], and proportional derivative controller [21]. Proportional controller is used to improve the transient response [22]. Integral controller is used to improve the steady state error by adding a pole at origin which increases the order of the system. Differential controller is used to improve the stability of the system rather than steady state error. Proportional integral (PI) controller improves the steady state stability by increasing the type of the system. Figure 4 depicts the block diagram of closed loop PI controller [23].
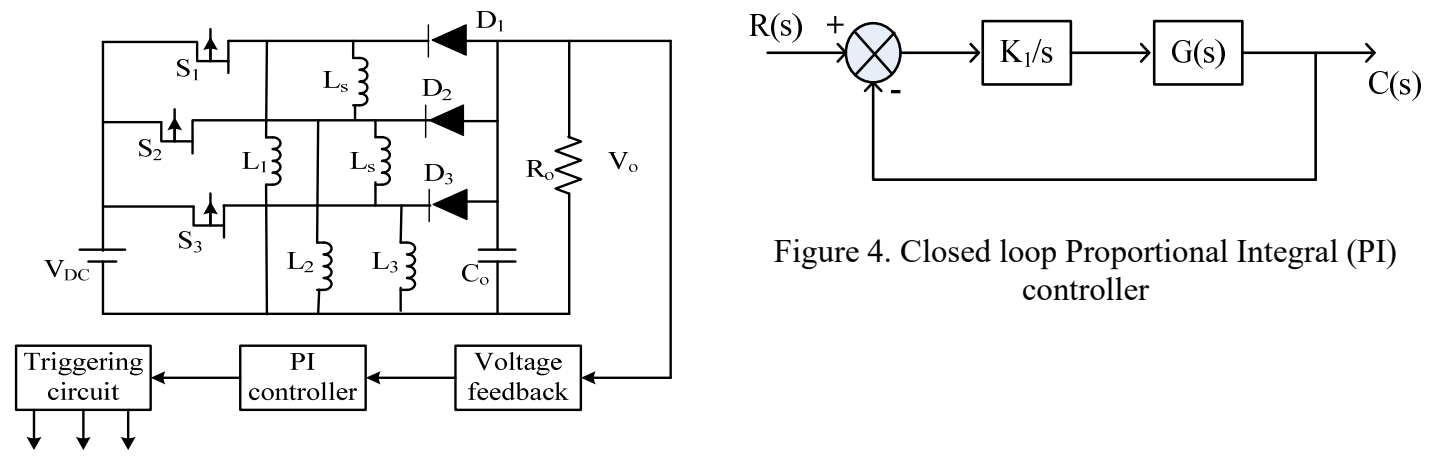

Figure 4. Closed loop Proportional Integral (PI) controller

Figure 3. Closed loop triple-deck buck-boost converter

In the proposed closed loop triple-deck buck-boost converter, the PI controller detects the error which in turn produces the required gain, and then it is fed to the forward path to get the required output [24].

\section{IMPLEMENTATION OF CLOSED-LOOP TRIPLE-DECK BUCK-BOOST CONVERTER}

Figure 5 depicts the implementation of a closed triple-deck buck-boost converter in MATLAB simulink software. In this circuit, an extra switch is attached and duty ratio of each switch is selected as 0.35 , to maitain the effective duty ratio as 0.7 . By using this duty ratio, higher voltage can be obtained in comparission to that of double-deck buck-boost converter. This significantly increases the gain and efficiency of the system [25]-[26].

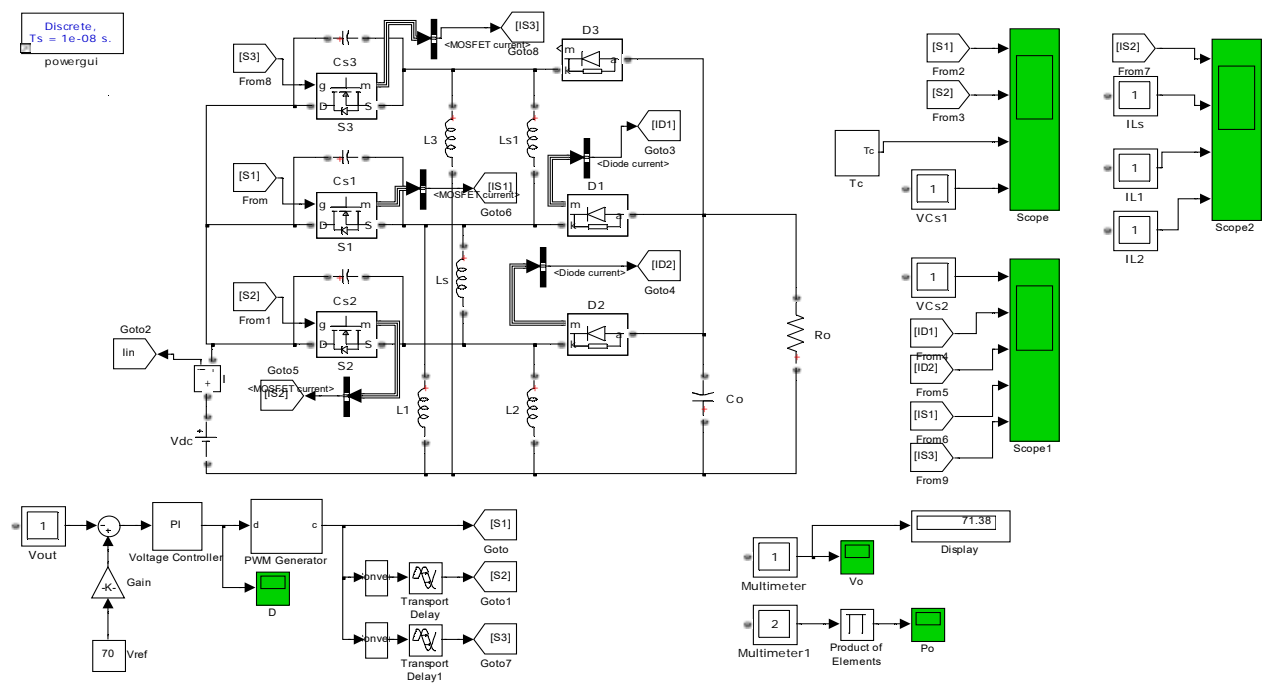

Figure 5. Implementation of closed-loop triple-deck buck-boost converter. 
This closed loop PI controller makes the output constant irespective of change in input, and there is an improvement in the stability of closed-loop system [27]-[28].

\section{RESULTS AND DISCUSSION}

The proposed triple-deck buck-boost converter is designed by selecting the effective duty ratio as 0.55 and the input, output voltages as $20 \mathrm{~V}$ and $50 \mathrm{~V}$, respectively. Output power is $100 \mathrm{~W}$ and the switching frequency is taken as $133 \mathrm{kHz}$ [29]-[30]. The circuit parameters considered in this work is: inductors (L1 and $\mathrm{L} 2)$ are $180 \mu \mathrm{h}$, inductor (Ls) is $30 \mu \mathrm{h}$, capacitor (Co) is $100 \mu \mathrm{F}$, type of power MOSFETS is IRF 640 , and the type of diode is BYV32. Switching and communication times considered as $7.5 \mu$ s and $30 \mu$ s. The output resistance is considered as $25 \Omega$. A $200 \mathrm{~W}$ power, $70 \mathrm{~V}$ output voltage, with 20-30 volts input, switching frequency of $133 \mathrm{kHz}$ prototype is analyzed [31], and the results are presented below:

Figure 6 depicts the output voltage obtained in the proposed triple-deck buck-boost converter.

Figure 7 depicts the output power of proposed triple-deck buck-boost converter.

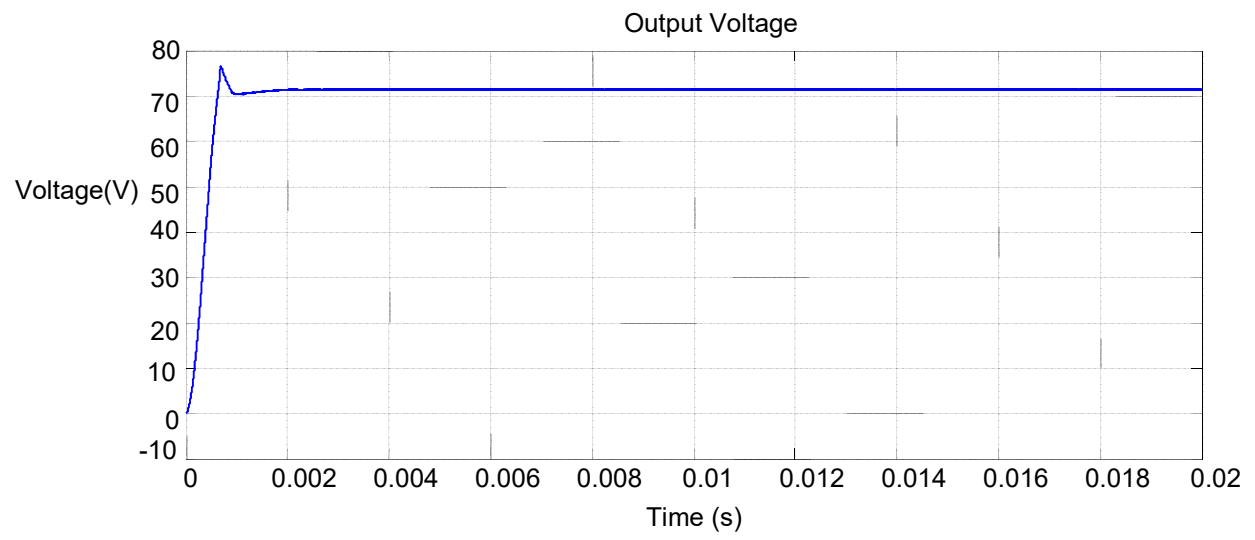

Figure 6. Output voltage of proposed triple-deck buck-boost converter

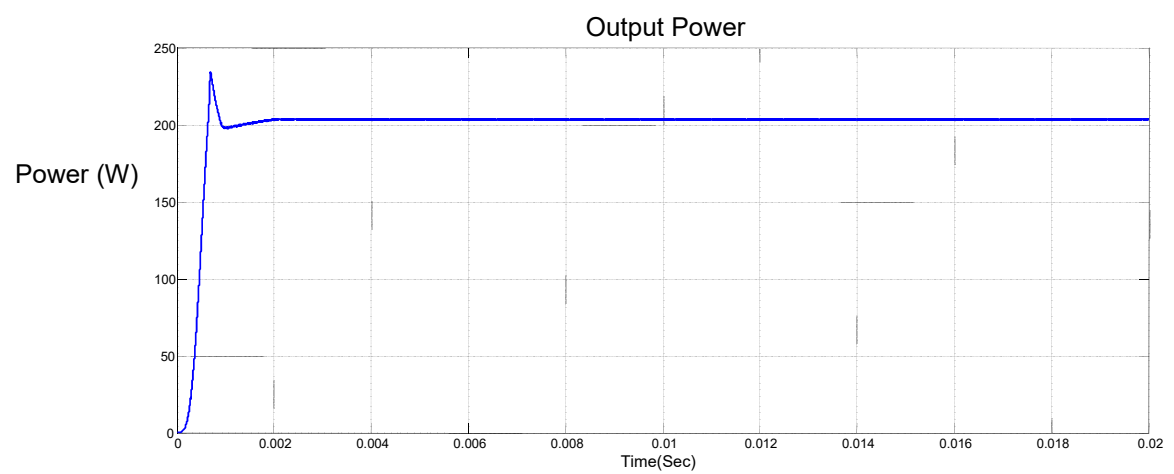

Figure 7. Output power of proposed triple-deck buck-boost converter

The obtained duty ratio of proposed triple-deck buck-boost converter is depicted in Figure 8 . Switching waveforms of gate voltages, communication time and intrensic voltage are depicted in Figure 9. Switching waveforms of intrensic voltage, diode currents and switch currents are depicted in Figure 10. Switching waveforms of switch current, interleaved inductor current and inductor currents are depicted in Figure 11 .

Int J Pow Elec \& Dri Syst Vol. 11, No. 1, Mar 2020 : 523 - 529 


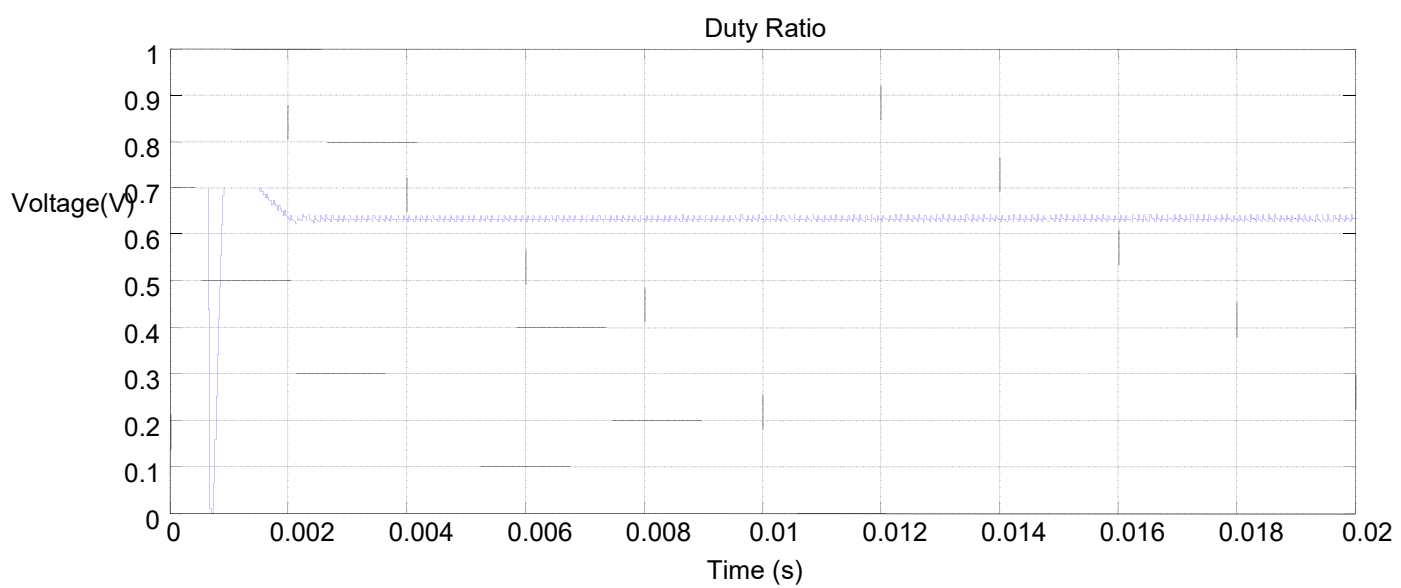

Figure 8. Duty ratio of proposed triple-deck buck-boost converter

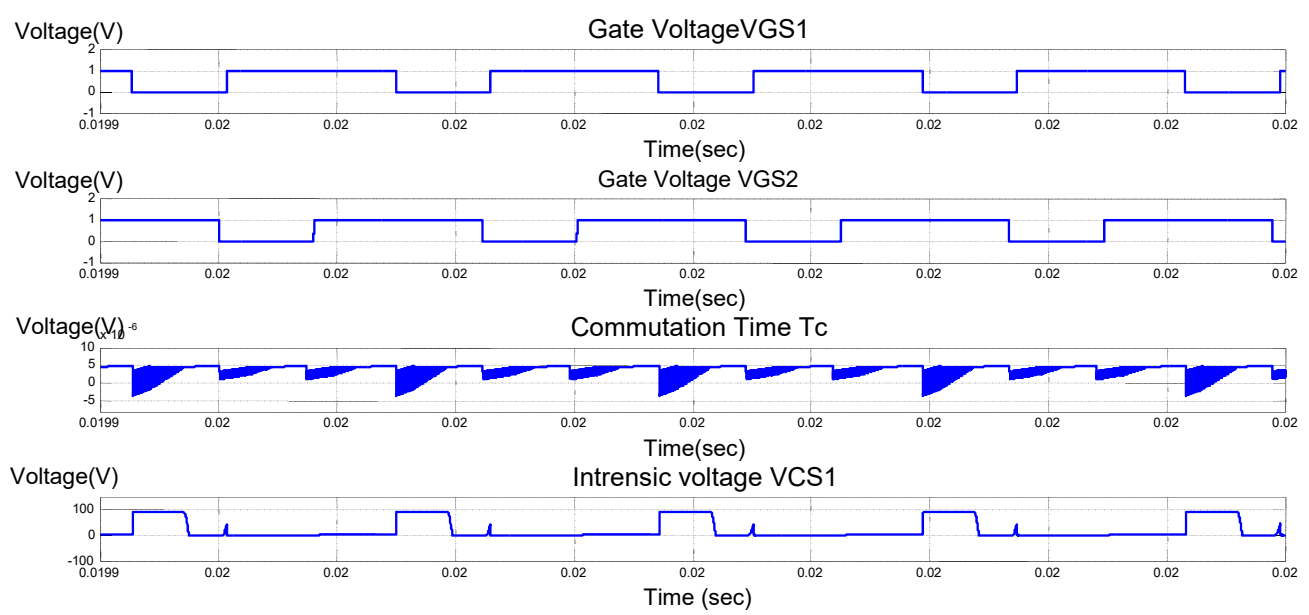

Figure 9. Switching waveforms of gate voltages, communication time and intrensic voltage

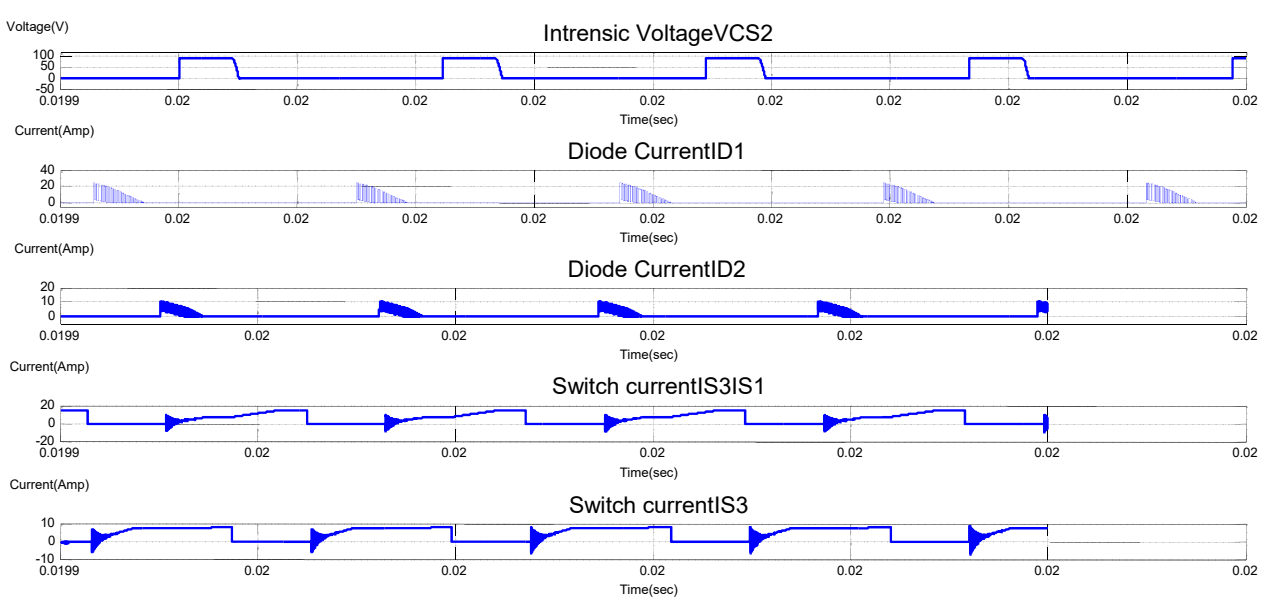

Figure 10. Switching waveforms of intrensic voltage, diode currents and switch currents 

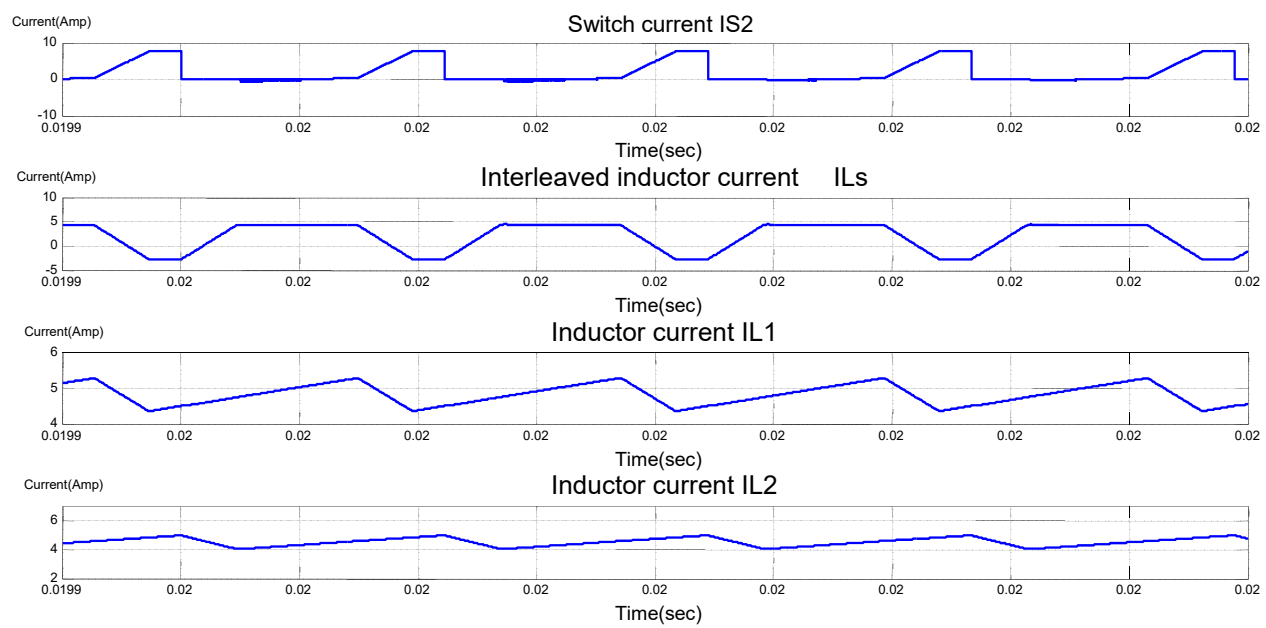

Figure 11. Switching waveforms of switch current, interleaved inductor current and inductor currents

From the above simulation results on closed loop triple-deck buck-boost converter with PI controller, it can be observed that it maintains the output voltage and power at constant magnitude. The main drawback of double-deck buck-boost converter is that it has high switching losses. However, the proposed one utilizes two converters in parallel, which reduces the ripples in the output voltage and also improves the gain of the system. The proposed triple-deck buck-boost converter is suitable for medium voltage and power levels.

\section{CONCLUSIONS}

A closed loop triple-deck buck-boost converter with high gain soft switching operation has been proposed in this paper. The soft switching operation of proposed closed-loop triple-deck buck-boost converter has been performed by operating the switches at zero switching intervals. This operation reduces the switching losses and ripples, which in turn improves the efficiency. The main control of closed loop controller is provided by proportional integral (PI) controller, which controls the output voltage as per the desired value and it is set by the reference voltage. A $200 \mathrm{~W}, 70 \mathrm{~V}$ output voltage with $(20-30) \mathrm{V}$ input, switching frequency of $133 \mathrm{kHz}$ prototype is analyzed and the simulation results are presented in this paper. Closed loop PI controller of proposed converter maintains the output voltage and power at constant magnitude. The proposed triple-deck buck-boost converter is ideal for medium voltage and power applications.

\section{ACKNOWLEDGEMENTS}

This research work has been carried out based on the support of "TKR College of Engineering and Technology's Academic Research Funding - (2019-2020)" and "Woosong University's Academic Research Funding - (2019-2020)".

\section{REFERENCES}

[1] M. Pavlovský, G. Guidi, A. Kawamura, "Buck/Boost DC-DC Converter Topology With Soft Switching in the Whole Operating Region," IEEE Transactions on Power Electronics, vol. 29, no. 2, pp. 851-862, Feb. 2014.

[2] E. Maali, B. Vahidi, "Double-Deck Buck-Boost Converter With Soft Switching Operation," IEEE Transactions on Power Electronics, vol. 31, no. 6, pp. 4324-4330, Jun. 2016.

[3] S.S. Dhanavathi, R. Anupama, "Battery Charging And Load Operation using Double Deck Soft Switching DC-DC Buck Boost Converter", International Journal of Innovative Technologies, vol. 5, no. 10, pp. 2003-2007, Oct. 2007.

[4] A. Pranay, G. Venumadhav, "Extendable multi-deck buck-boost converter with soft switching operation", International Journal of Research, vol. 7, no. 12, pp. 1403-1407, Dec. 2018.

Int J Pow Elec \& Dri Syst Vol. 11, No. 1, Mar 2020 : 523 - 529 
[5] G. Prithivi, P. Madasamy, "Parallel Connected Buck-Boost Converter for PV Application Using Pi Controller", International Journal of Advanced Research in Electrical, Electronics and Instrumentation Engineering, vol. 7, no. 2, pp. 762-769, Feb. 2018.

[6] K. Gopinath, B. Jyosthna, "A Double-Deck Buck-Boost Converter with Soft Switching Operation for Renewable Energy Applications", International Journal of Science, Engineering and Technology Research, vol. 6, no. 1, pp. 160-165, Jan. 2017.

[7] K.V.K. Varma, A. Ramkumar, "A Novel M-SEPIC DC-DC Converter for BLDC Pumping System with Active PFC using ANFIS Controller", Indonesian Journal of Electrical Engineering and Computer Science, vol. 11, no. 1, pp. 386-399, Jul. 2018.

[8] K.N. Gayathry, A. Xavier, "Double-Deck Buck-Boost Converter for Power Electronic Applications", International Journal for Scientific Research \& Development, vol. 5, no. 3, pp. 602-606, 2017.

[9] P. Manikandan, S.D. Bharath, K.B. Khati, D.P. Krishna, "A Single Switch Non-Isolated Transformerless DC-DC Buck Boost Converter", International Journal of Advanced in Management, Technology and Engineering Sciences, vol. 8, no. 2, pp. 738-745, Feb. 2018.

[10] C.J. Solomon, K.D. Joseph, "Resonant Parallel Operated Buck - Boost Converter in ZVS mode with Voltage Regulation", International Journal of Advanced Research in Computer and Communication Engineering, vol. 8, no. 1, pp. 191-201, Jan. 2019.

[11] P.P. Hieu, Y.C. Hsieh, J.Y. Lin, B.S. Huang, H.J. Chiu, "A novel active-clamp zero-voltage-switching buck-boost converter", International Journal of Circuit Theory and Applications, vol. 46, no. 4, pp. 868-881, Apr. 2018.

[12] R. Palanisamy, K. Vijayakumar, V. Venkatachalam, R.M. Narayanan, D. Saravanakumar, K. Saravanan, "Simulation of various DC-DC converters for photovoltaic system", International Journal of Electrical and Computer Engineering, vol. 9, no. 2, pp. 917-925, Apr. 2019.

[13] Suwarno, T. Sutikno, "Implementation of buck-boost converter as low voltage stabilizer at 15V", International Journal of Electrical and Computer Engineering, vol. 9, no. 4, pp. 2230-2237, Aug. 2019.

[14] M. Ado, A. Jusoh, A.U. Mutawakkil, T. Sutikno, "Dynamic model of a DC-DC quasi-Z-source converter (qZSC)", International Journal of Electrical and Computer Engineering, vol. 9, no. 3, pp. 1585-1597, Jun. 2019.

[15] M.Z. Zulkifli, M. Azri, A. Alias, N. Talib, J.M. Lazi, "Simple control scheme buck-boost DC-DC converter for standalone PV application system", International Journal of Power Electronics and Drive System, vol. 10, no. 2, pp. 1090-1101, Jun. 2019.

[16] W.A. Memala, C. Bhuvaneswari, S.M. Shyni, G.M. Sheeba, M.S. Mahendra, V. Jaishree, "DC-DC converter based power management for go green applications", International Journal of Power Electronics and Drive System, vol. 10, no. 4, pp. 2046-2054, Dec. 2019.

[17] J. Hong, H. Lee, K. Nam, "Charging method for the second battery in dual inverter drive systems for electric vehicles," IEEE Applied Power Electronics Conference and Exposition, Fort Worth, TX, 2014, pp. 2407-2414.

[18] B. Mahdavikhah, A. Prodić, "Low-Volume PFC Rectifier Based on Nonsymmetric Multilevel Boost Converter," IEEE Transactions on Power Electronics, vol. 30, no. 3, pp. 1356-1372, Mar. 2015.

[19] J. Chen, P. Shen, Y. Hwang, "A High-Efficiency Positive Buck-Boost Converter With Mode-Select Circuit and Feed-Forward Techniques," IEEE Transactions on Power Electronics, vol. 28, no. 9, pp. 4240-4247, Sept. 2013.

[20] Y. Chen, S. Shiu, R. Liang, "Analysis and Design of a Zero-Voltage-Switching and Zero-Current-Switching Interleaved Boost Converter," IEEE Transactions on Power Electronics, vol. 27, no. 1, pp. 161-173, Jan. 2012.

[21] B. Gu, J. Dominic, B. Chen, L. Zhang, J. Lai, "Hybrid Transformer ZVS/ZCS DC-DC Converter With Optimized Magnetics and Improved Power Devices Utilization for Photovoltaic Module Applications," IEEE Transactions on Power Electronics, vol. 30, no. 4, pp. 2127-2136, Apr. 2015.

[22] A. Mostaan, S.A. Gorji, M.N. Soltani, M. Ektesabi, "A novel single switch transformerless quadratic DC/DC buckboost converter," 19th European Conference on Power Electronics and Applications, Warsaw, 2017, pp. 1-6.

[23] M. Ado, A. Jusoh, M. J. Abdul Aziz, M. Kermadi and A. U. Mutawakkil, "DC-DC q-ZSC with Buck-Boost Converter Gain," 9th IEEE Control and System Graduate Research Colloquium, Shah Alam, Malaysia, 2018, pp. $85-88$.

[24] S. Narasimha, S. Surender Reddy, "Design and implementation of smart uninterruptable power supply using battery storage and photovoltaic arrays", International Journal of Engineering \& Technology, vol. 7, no. 3, pp. 960-965, May 2018.

[25] J.S. Yu, G. Jin, S.L. Cheng, W.T. Ng, "Digital dead-time control for an integrated tri-mode buck-boost DC-DC converter," 9th International Conference on Power Electronics and ECCE Asia, Seoul, 2015, pp. 1768-1771.

[26] S. Narasimha, S. Surender Reddy, "Dynamic and Hybrid Phase Shift Controller for Dual Active Bridge Converter", International Journal of Engineering \& Technology, vol. 7, no. 4, pp. 4795-4800, 2018.

[27] P.F. Liya, K.V. Aathira, "A coupled inductor buck-boost DC-DC converter with wide voltage conversion range," International Conference on Circuits, Power and Computing Technologies, Nagercoil, 2014, pp. 708-713.

[28] S. Narasimha, S. Surender Reddy, "An improved closed loop hybrid phase shift controller for dual active bridge converter", International Journal of Electrical and Computer Engineering (IJECE), Vol. 10, No. 2, pp. 1169-1178, Apr. 2020.

[29] A.V. Magar, S.G. Kanade, A.P. Kinge, "Transformerless Buck-Boost DC-DC Converter," IEEE Global Conference on Wireless Computing and Networking, Lonavala, India, 2018, pp. 200-203.

[30] Y. Li, T.Q. Zheng, C. Zhao, R. Du, Q. Wang, "A novel buck/boost/buck-boost three-input DC/DC converter," 37th Annual Conference of the IEEE Industrial Electronics Society, Melbourne, VIC, 2011, pp. 1091-1096.

[31] J. Fu, B. Zhang, D. Qiu, W. Xiao, "A novel single-switch cascaded DC-DC converter of Boost and Buck-boost converters," 16th European Conference on Power Electronics and Applications, Lappeenranta, 2014, pp. 1-9. 